\title{
An empirical analysis of rural and urban populations' access to electricity: evidence from Pakistan
}

\author{
Abdul Rehman ${ }^{1 *}$, Zhang Deyuan ${ }^{1}$, Abbas Ali Chandio ${ }^{2}$ and Imran Hussain ${ }^{3}$
}

\begin{abstract}
Background: This study explores the electricity access to rural and urban populations and its impact on the economic growth in Pakistan.

Methods: An autoregressive distributed lag (ARDL) bounds testing approach was applied, and a co-integration test was used to investigate the dynamic causality relationships between the study variables. By using this testing approach, this study filled the literature gap regarding the access of rural and urban population to electricity in Pakistan.

Results: The tests shed light on the long-run relationship among the variables, whereas the results revealed that the access of both rural and urban populations to electricity had a positive and significant effect on economic growth.

Conclusions: According to these findings, we can conclude that Pakistan should pay further attention to increasing its electricity production from different sources, including not only hydroelectric, solar, wind, oil, gas, and biomass but also fewer and fewer nuclear sources, in order to fulfill the country's demands on its way to a future of sustainable development.
\end{abstract}

Keywords: Electricity, Economic growth, Rural population, ARDL, Urban population

\section{Background}

A region's energy supply is a key determinant of its economic development and social prosperity. With the rapid development of science and continuous innovations in technology, energy utilization is also constantly expanding. As a result, the energy demand has increased while resources have become strained from the burden [1]. Pakistan's electricity sector is made up of two vertically integrated public sector utilities: the Water and Power Development Authority and the Karachi Electric Supply Company. Approximately 16 independent power producers have provided significant contributions to power generation in Pakistan. In recent years, Pakistan's power generation has decreased by $50 \%$ due to its over-reliance on hydroelectric power. In 2008, Pakistan's electricity power supply was below the demand of the population, which was $15 \%$ [2].

\footnotetext{
* Correspondence: abdlrehman@ahu.edu.cn

'Research Center of Agricultural-Rural-Peasants, Anhui University, Hefei, China Full list of author information is available at the end of the article
}

Pakistan's electricity generation sector is a mixed industry of hydropower, heat, and nuclear power plants. About $31 \%$ of its electricity is produced by hydroelectric systems, $66.8 \%$ comes from thermal systems, and the remaining $2.2 \%$ is generated from nuclear power. The country imported $29.4 \%$ of its natural gas, $37.8 \%$ of its oil, $29.4 \%$ of its hydropower, and $0.26 \%$ of its natural gas to meet its energy needs. Contributions of coal and nuclear energy to its energy supply are currently limited to $0.1 \%$ and $3.02 \%$, respectively $[3,4]$. Unless every country is now experiencing this same sporadic crisis that is combined with growing energy consumption and environmental costs, all governments around the world are forced to further focus on monitoring and managing their energy markets [5].

Pakistan's population has grown from 79.98 million in 1980 to 276.17 million in 2012. The country's growing population, industrialization, and increasing average household income have contributed to the growth of electricity demand [6-9]. It is worth noting that domestic sectors use electricity most heavily, at an average 
annual rate of $15.1 \%$. As a result, the general population suffers the most when a serious electricity shortage occurs in Pakistan. Electricity consumption in the commercial sector increased by an average of $11.1 \%$ annually, and in 2014, Pakistan's population increased at a rate of $2 \%$ annually [10]. On the electricity supply side, compared to the demand rate of about $10 \%$ per annum, the power generation only increased at an average annual rate of $6 \%$. As a result, the cumulative effect of the electricity supply-and-demand gap has adversely affected Pakistan's economy. In 2014, the power shortage reached 5000 MW [11].

The agricultural sectors of developing countries in the South Asian region play an important role in their economies [12, 13]. In developing countries such as Pakistan, the majority of the rural population is not connected to the electrical grid. In addition, power grids in rural areas, especially during the summer months, experience power shortages for up to $18 \mathrm{~h}$ per day. Off-grid generation via indigenous resources might help to reduce such power shortages and provide electricity to rural areas that lack access to the national grid $[14,15]$. These power shortages have caused enormous damage to Pakistan's economy and created binding and forceful restrictions to the country's growth. They limit the growth of gross domestic product (GDP) and have a very serious negative impact on employment, international competitiveness, exports, and poverty reduction. For ordinary citizens, the heavy load reduction has caused serious damage to their daily lives. For the industrial, commercial, and agricultural sectors, the cost of electricity shortages is enormous, and Pakistan's overall economy has been greatly weakened. For example, more than half of its textile exports and about $40 \%$ of its manufacturing jobs, including small businesses, have also been affected [16-18]. Energy in the form of electricity production plays a vital role in the overall growth of a country and in other industries. A sustainable means of electricity production can improve a country's economy, quality of life, and social well-being. At this stage, the role of policymakers is not only to assess and review current strategies to reduce the gap between electricity supply and demand, but also to develop future strategies to ensure affordable electricity that is effectively distributed to contribute to a sustainable development in the country [19-23].

Natural gas, oil, coal, biomass, hydropower, wind, and solar energy are basic foundations for local and industrial usage of energy. It is found that Pakistan's wind power potential is much higher than that of solar power generation, regardless of a high potential for solar power concentration. In addition, the best wind and solar power combination shows that $95 \%$ of wind power and $5 \%$ of solar power generation result in the lowest power shortage. The climatic conditions and geographic location of the country do provide a high solar energy potential, which means that solar energy resource assessments are needed for the planning of solar energy projects [24-26]. Solar energy might be an alternative means of producing electricity, but the country lacks modern solar technology. Likewise, it is important to initiate and direct the efficient usage of energy producing sources, their extraction, infrastructure, and development. The government of Pakistan may launch microfinance schemes to support the production of electricity from solar and bioenergy sources, and top priority should now be given to an urgently needed adequate, reliable, and affordable electricity supply. Also, necessary policies should pursue an increase of indigenous electricity production from gas and other reliable sources to meet the country's growing energy needs.

The major aim of this study was to explore the access of rural and urban populations to electricity and its influence on the economic growth in Pakistan. An augmented Dickey-Fuller unit root test was used to investigate the stationarity of the variables, whereas an autoregressive distributed lag (ARDL) bounds testing approach to co-integration was employed to check the association among the study variables using long-run and short-run relationships.

Aside from the background section, the rest of the article is organized as follows: The section "The current electricity situation in Pakistan" provides the current electricity situation in Pakistan; the "Materials and methods" section describes the data sources and empirical model specification. The "Empirical estimation strategy" section specifies the unit root test for the stationarity of the variables and the co-integration with the auto regressive distributed lag (ARDL) Model. The "Results and discussion" section presents the results of the unit root test, the co-integration test, the long-run relations, the short-run relations, and the structural stability test. Finally, the "Conclusion and policy implication" section provides the policy recommendations in terms of electricity production from different alternatives as well as the short-term and long-term policies.

\section{The current electricity situation in Pakistan}

Pakistan's power sector is facing its worst crisis to date. It supports an overloaded infrastructure and is under capacity, which makes it vulnerable to unprecedented load shedding, excessive loss of transmission and distribution, and a large amount of revolving debt. According to Pakistan's Electric Power Company data, in April 2011, the country generated more than $5000 \mathrm{MW}$ of electricity, but the country's demand stood at 14,475 MW, leaving a shortage of $9475 \mathrm{MW}$. Some rural areas experienced load shedding and blackouts for up to $20 \mathrm{~h}$ per day, while load shedding in the city areas increased 
to $14 \mathrm{~h}$ per day. In May 2012, the shortage increased to $6000 \mathrm{MW}$, at an estimated demand of 15,000 MW, whereas the supply amounted to only $9000 \mathrm{MW}[27,28]$. Under the current policy, the supply gap is expected to continue as it is estimated that starting from 2017, electricity shortages will increase to $8000 \mathrm{MW}$, hitting $13,000 \mathrm{MW}$ in 2020 [29].

Pakistan's electricity demand is partly driven by factors such as population growth, economic expansion, electricity prices, people's movement in cities, and the weather. However, the problems that are specific to Pakistan and the crisis that has caused its electricity shortage are due to theft and overuse of electricity in domestic and industrial sectors, resulting in a huge loss of power lines, low institutional capacity, corruption, mismanagement, and political controversy in mega-power projects [30]. Policymakers should be fully aware of future electricity use projections so that they can take appropriate steps to close the gap. Various studies have been conducted focusing on the needs of Pakistan's electricity sector [31, 32], electricity sources, and their residential consumption [33, 34].

Electricity infrastructure planning and the growing demand in electricity and GDP are interrelated, especially in developing countries such as Pakistan. Pakistan has a one-way causal link between economic activity and electricity use, which points to an increase in electricity demand and to a higher economic growth [35]. Hence, the demand for electricity has unexpectedly increased due to a steady 6\% growth in GDP from 2002 to 2007; however, without proper infrastructure planning in the power sector, the country has faced severe power outages, resulting in a $2.5 \%$ loss of GDP, 53.5 million industrial workers out of work, and export losses worth $\$ 1.3$ billion in 2010 [36]. The per capita electricity consumption in Pakistan increased from 457 to $640 \mathrm{kWh}$, which amounts to about one fourth of the world average [37]. The installed capacity of electricity increased to 25.1 million megawatts (MW) in 2017 and from 22.9 million megawatts (MW) during the corresponding period last year; however, generation declined from $101,970 \mathrm{GW} / \mathrm{h}$ in 2016 to $85,206 \mathrm{GW} / \mathrm{h}$ in 2017 . A slowdown in the share of hydropower in electricity generation caused a decline of 34\% during the corresponding period of 2017. This mainly occurred due to less flow of water in rivers and difficult weather conditions [38].

The barriers to rural electrification are economic, legal, fiscal, and institutional ones [39]. Having appropriate authorities is also a condition for innovation in electrical access as well as for public-private partnerships. In addition, they are crucial to raising the funds that are necessary to extend power access $[40,41]$. It is worth noting that an appropriate institutional and policy design is often obstructed by vested interests. Therefore, successful countries often employ bottom-up approaches that involve local citizens in their electrification plans [42-45].
The future direction of energy policy is based on wide-ranging economic parameters as well as environmental and political factors that determine which technologies should be deployed to meet future energy needs. Pakistan's electricity sector is facing its worst financial crisis ever in terms of its energy dynamics. Its electricity sector has tragically failed due to substandard maintenance of power plants, erroneous predictions that led to downsizing of employees, misuse of electricity subsidies, and mixed energy, resulting in a shortage of $7000 \mathrm{MW}$ [46]. According to the Special Parliamentary Committee which handled the energy crisis of 2011, an accumulated circulating debt worth $\$ 6.6$ billion was calculated [47]. In the short term, two key issues are being resolved on a fast track. One problem is the inefficient recovery system, and the other is transmission and distribution losses. The Ministry of Water and Power has shown significant improvement of both issues. During 2016, the recovery ratio amounted to 94.40 as compared to the past 10 years while the distribution and transmission losses declined to $16.3 \%$ during the aforementioned period [48]. Policymakers should therefore be fully aware of future electricity use so that appropriate measures can be taken to bridge this gap. In Pakistan, various studies have been conducted on sectorial level electricity needs $[31,49,50]$.

Electricity access among rural and urban populations and economic growth from 1990 to 2014 are illustrated in Figs. 1, 2, 3, and 4.

\section{Materials and methods}

\section{Data sources}

This study explores the access of electricity to the rural and urban population and its impact to the economic growth in Pakistan over a period from 1991 to 2014. Time series data were collected from an economic survey of Pakistan and World Development Indicators (WDI). The variables used in this study are gross domestic product (annual \%), electricity access to the rural

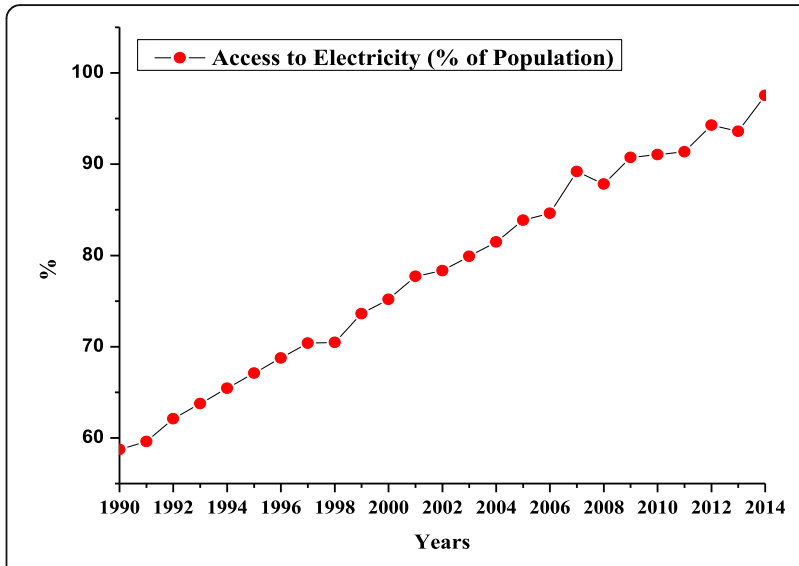

Fig. 1 Access to electricity (\% of population) 


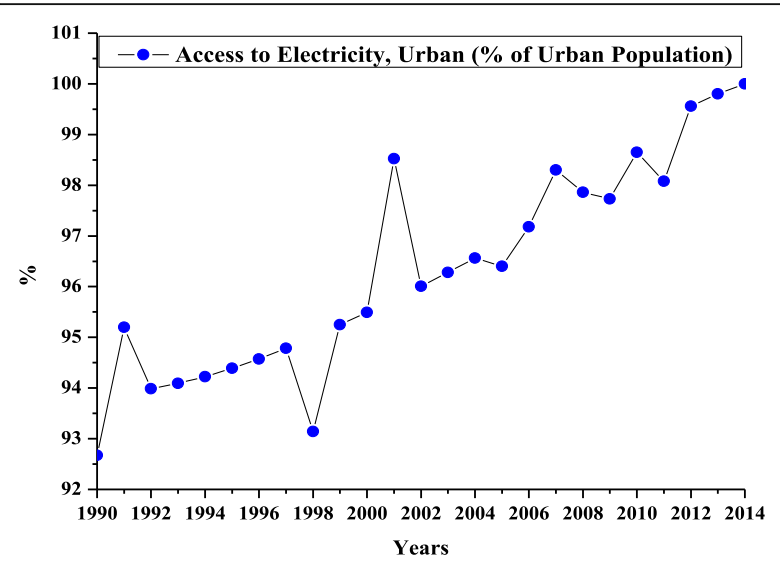

Fig. 2 Access of the urban population to electricity

population (\% of total), and electricity access to the urban population (\% of total), respectively.

\section{Empirical model specification}

In order to explore and examine the long-run and short-run analysis and the linkage between electricity access to the rural and urban population and its impact to economic growth in Pakistan, this study employed a multivariate regression model specified as:

$$
\mathrm{GDP}_{t}=\beta_{0}+\beta_{1} \mathrm{EATRP}_{t}+\beta_{2} \mathrm{EATUP}_{t}+\varepsilon_{t}
$$

By using a natural logarithm to Eq. 1, a log-linear model is as follows:

$$
\operatorname{lnGDP}{ }_{t}=\beta_{0}+\beta_{1} \ln \text { EATRP }_{\mathrm{t}}+\beta_{2} \operatorname{lnEATUP}_{\mathrm{t}}+\varepsilon_{t}
$$

Whereas $\operatorname{lnGDP}_{t}$ indicates the natural logarithm of gross domestic product (GDP), $\operatorname{lnEATRP}_{t}$ indicates the natural logarithm of the access of the rural population to electricity, $\operatorname{lnEATUP}$ represents the natural logarithm of the access of the urban population to electricity, $t$

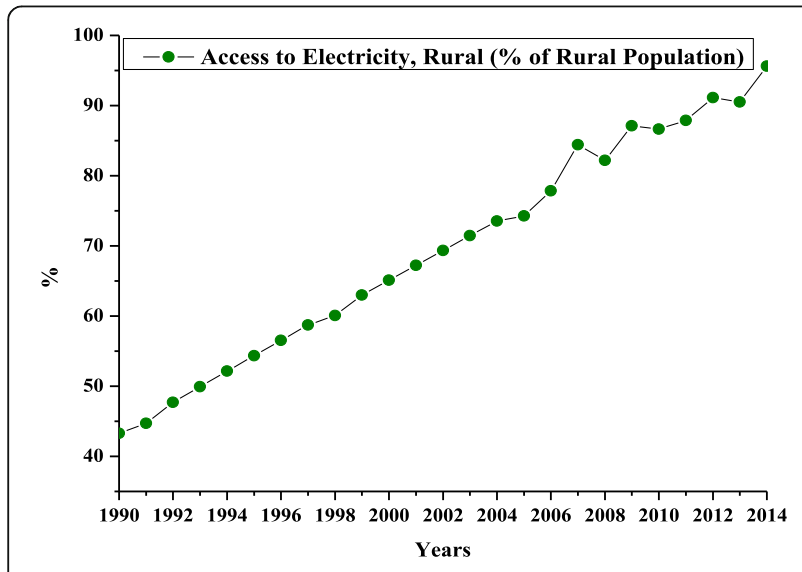

Fig. 3 Access of the rural population to electricity

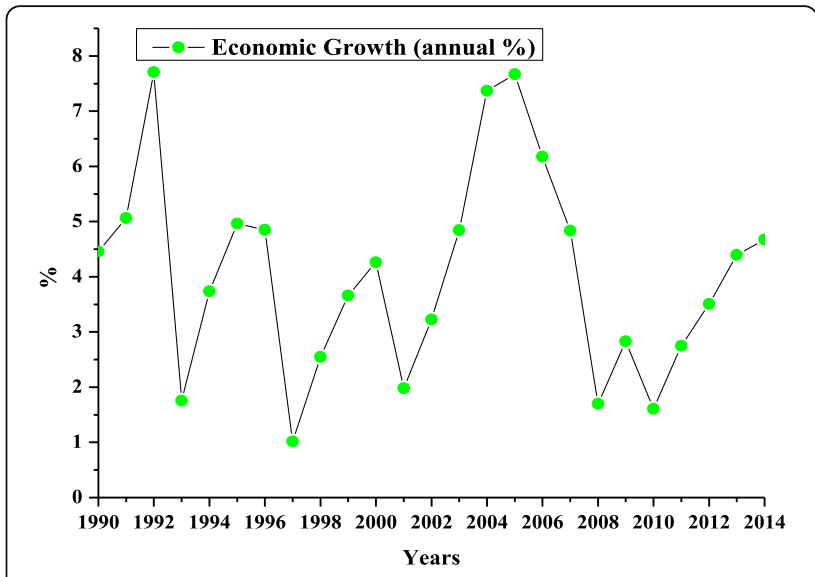

Fig. 4 Economic growth of Pakistan in \%

denotes the time dimension, and $\varepsilon_{t}$ denotes the error term. Equation 2 represents the $\log$-linear form of the variables. The coefficients of the model $\beta_{1}$ to $\beta_{2}$ represent the elasticity of the long-run.

\section{Empirical estimation strategy \\ Unit root test for stationarity}

Despite the fact that the auto regressive distributed lag (ARDL) model requires no pre-testing for checking the unit root test for the stationarity of the variables, augmented Dickey-Fuller (ADF) [51] unit root tests, including trend and intercept, were used to determine that none of the variables considered were integrated to order 2. As an ARDL bounds testing approach is invalidated in cases where $I(2)$ variables are used, an ADF unit root test was performed using Eq. 3.

$$
\Delta M_{t}=\alpha_{\circ}+\beta_{\circ} T+\beta_{1} M_{t-1}+\sum_{i=1}^{m} \alpha_{1} \Delta M_{t-1}+\mu_{t} .
$$

where $M$ indicates the variables being tested for the unit root, $T$ represents a linear trend, $\Delta$ indicates the first difference, $t$ shows the time, $\mu_{t}$ is the error term, and $m$ represents how to achieve white noise residuals.

\section{Co-integration with the auto regressive distributed lag model}

To check the long-run and short-run relationship between the dependent and independent variables, this empirical study used an ARDL bounds testing approach which was developed by Pesaran and Shin [52] and which was further extended by Pesaran et al. [53] and Narayan [54]. The co-integration testing approach is applicable regardless of the order of integration with the concerned variables, $I(0)$ and or $I(1)$, except for the presence of $I(2)$. The long-run and short-run relationship examined the ARDL 
representation of the unrestricted error correction model (UECM) of Eq. (2), as depicted in Eq. (4):

$$
\begin{aligned}
& \Delta \operatorname{lnGDP}_{t}=\alpha_{0}+\sum_{i=1}^{p} \alpha_{1 i} \Delta \operatorname{lnGDP} \operatorname{CD}_{t-i}+\sum_{i=1}^{q^{1}} \alpha_{2 i} \Delta \operatorname{lnEATRP} \operatorname{PA}_{t-i} \\
& +\sum_{i=1}^{q^{2}} \alpha_{3 i} \Delta \operatorname{lnEATUP} t-i+\beta_{1} \operatorname{lnGDP}_{t-1}+\beta_{2} \operatorname{lnEATRP}_{t-1} \\
& +\beta_{3} \operatorname{lnEATUP} \operatorname{Pi}_{t-1}+\varepsilon_{t}
\end{aligned}
$$

where $\Delta$ indicates the difference operator and $\beta$ indicates the coefficients of long-run, while $\alpha$ captures the coefficients of the short-run. The long-run co-movement among the variables of interest is ascertained on the basis of the estimated F-statistic. Pesaran et al. constituted two values available for the test of co-integration: (1) lower bound critical values, where the variables are integrated to order zero [i.e., $I(0)$ ], and (2) upper bound critical values where the variables are integrated to order one [i.e., $I(1)]$. The hypothesis of no presence of a longrun association is rejected when an estimated $F$-statistics exceeds the upper bound critical values. Eventually, this empirical study allows the long-run elasticity and shortrun adjustment parameters in Eq. 4 to be investigated.

\section{Results and discussions}

\section{Results of unit root test}

A unit root test was performed solely with the augmented Dickey-Fuller (ADF) test by considering the levels of the variables, first with an intercept and with both intercept and trend and subsequently the test was extended to include the first difference of the variables that were not stationary as could be seen in the Table 1 .

The unit root test indicates that no variable was integrated with an order of $I(2)$ and that the ARDL model applied.

\section{Results of the co-integration test}

A co-integration test was used when an $F$ or $W$ statistic was applied to the upper bound of the selected significant level. It is worth noting that the " $F$ " test assumes that there is no co-integration null hypothesis between the variables. The various statistics are reported in Table 2.

The bounds tests shown in the table pointed to the existence of a co-integration relationship between

Table 1 ADF unit root test (trend and intercept)

\begin{tabular}{llll}
\hline Variables & Levels & First Difference & Conclusion \\
\hline InGDP & $-3.631807^{* *}$ & $-5.990866^{* * *}$ & $I(0)$ \\
InEATRP & $-4.106528^{* *}$ & $-6.462204^{* * *}$ & $I(0)$ \\
InEATUP & $-3.957877^{* *}$ & $-7.265927^{* * *}$ & $I(0)$ \\
\hline
\end{tabular}

$*_{* * *}^{* * *}$ denote the rejection of the null hypothesis of unit root at the $1 \%, 5 \%$, and $10 \%$ significant level, respectively
Table 2 ARDL bounds test for co-integration results

\begin{tabular}{lllll}
\hline F-statistic & $\begin{array}{l}\text { Significance } \\
\text { level (\%) }\end{array}$ & $\begin{array}{l}\text { Lower } \\
\text { bound }\end{array}$ & $\begin{array}{l}\text { Upper } \\
\text { bound }\end{array}$ & Decision \\
\hline 4.615547 & 10 & 3.17 & 4.14 & Co-integrated \\
& 5 & 3.79 & 4.85 & \\
& 1 & 5.15 & 6.36 & \\
\hline
\end{tabular}

economic growth and all independent variables at $1 \%$, $5 \%$, and $10 \%$.

\section{Results of the long-run relations}

The results of the long-run relations are presented in Table 3.

In the model that focused on the elasticity of the variables, the results revealed that electricity access to the rural population has a coefficient of 0.338627 , which is positive and significant with a $p$ value of 0.0195 . This means that a $1 \%$ increase in the access of electricity to the rural population with its explanatory power of 0.338 also points to increases in economic growth of $0.338 \%$. The coefficient of the access of the urban population to electricity also has a positive impact on economic growth with a coefficient of 0.638461 and a $p$ value of 0.0133, respectively. Various aspects of Pakistan's power sector have been considered, such as the gap between supply and demand, energy supply reduction, energy security, and increased energy costs. Furthermore, the energy status and potential of renewable energy have been discussed as a sustainable alternative. The model also discusses the role of different sectors of renewable energy technologies in promotion and development $[50,55]$. A total of 20 sustainability indicators were evaluated, including the life cycle of the seven power sources currently in use. The rankings of these sources also weigh the sustainability aspects and their respective indicators. Hydropower is considered to be the most sustainable option with a minimal environmental and economic impact. Because it causes the most significant economic and social impact, oil is considered the least sustainable option for the country $[56,57]$.

\section{Results of short-run relations}

The existence of a cointegration relationship among the variables requires an error correction model (ECM) to

Table 3 Results of long-run relationship

\begin{tabular}{lllll}
\hline Dependent variable is $\operatorname{lnGDP}$ & & & \\
\hline Regressors & Coefficients & Std. error & T-ratio & $p$ value \\
\hline InEATRP & 0.338627 & 0.133282 & 2.540681 & 0.0195 \\
InEATUP & 0.638461 & 0.234982 & 2.717061 & 0.0133 \\
$C$ & -3.233853 & 1.349736 & -2.395916 & 0.0265 \\
\hline
\end{tabular}


capture the short-run dynamics of the system and its coefficient, which measures the speed of adjustment to obtain equilibrium in the event of shocks to the system. Table 4 depicts the results of the short-run dynamic growth equation.

The short-run dynamics of the model were estimated using an $R$-squared value of approximately $39 \%$, meaning that approximately $39 \%$ of the variation in agricultural growth was explained by the independent variables in the model. The F-statistics confirmed the joint significance of all of the independent variables at the $1 \%$ significance level. The DW statistics was 1.662 , which was not equal to the standard DW value for the proof of absence of any autocorrelation; however, it was great enough to debunk the presence of any autocorrelation in the model. The short-run relationship indicated that the coefficient of electricity access to the rural population had a significant effect on agricultural growth. Likewise, the coefficients of access of electricity to the urban population had a significant effect on agricultural growth. The establishment of new lines and substations alone will not allow us to achieve the goal of overcoming energy shortages. As a result, a major shift in the power infrastructure will take time to meet the growing power demands. Converting the current power management system into an intelligent autonomous system is meant to achieve an increase in the amount of renewable energy generated. The main reason for the increase in the supply and demand gap is an increase in electricity demand, on the one side, and energy resources and financial constraints, on the other. Therefore, the government has implemented various initiatives, including a partial reorganization of the power sector in accordance with the guidance of international finance institutions $[21,58]$.

The results of the diagnostic and stability tests are presented in Table 5.

Table 4 Results of short-run error correction representation

\begin{tabular}{|c|c|c|c|c|}
\hline \multicolumn{5}{|c|}{ Dependent variable is InGDP } \\
\hline Regressors & Coefficients & Std. error & T-ratio & $p$ value \\
\hline$\Delta \operatorname{lnGDP}(-1)$ & 0.011487 & 0.185176 & 0.062034 & 0.9512 \\
\hline$\Delta$ InEATRP & 0.334737 & 0.135946 & 2.462270 & 0.0230 \\
\hline$\triangle \operatorname{lnEATUP}$ & 0.631127 & 0.228840 & 2.757945 & 0.0121 \\
\hline C & -3.196705 & 1.282868 & -2.491843 & 0.0216 \\
\hline $\mathrm{ECM}(-1)$ & -0.988513 & 0.185176 & -5.338221 & 0.0000 \\
\hline \multicolumn{2}{|c|}{$R$-squared 0.397976} & \multicolumn{3}{|c|}{ Durbin-Watson stat 1.662156} \\
\hline \multicolumn{2}{|c|}{$\begin{array}{l}\text { Adjusted } R \text {-squared } \\
0.307672\end{array}$} & F-statistic 4.407081 & \multicolumn{2}{|c|}{$\begin{array}{l}\text { Prob(F-statistic) } \\
0.015547\end{array}$} \\
\hline
\end{tabular}

Table 5 Diagnostic and stability tests

\begin{tabular}{ll}
\hline Test statistics (LM version) & Statistics (prob-values) \\
\hline Breusch-Godfrey serial correlation LM test & $1.643099(0.2211)$ \\
J-B normality test & $0.835475(0.658535)$ \\
Heteroskedasticity test: ARCH & $0.398109(0.5349)$ \\
\hline
\end{tabular}

$p$ values are given in the parenthesis

Table 5 depicts the results of the diagnostic and stability tests, including the Breusch-Godfrey serial correlation LM test, the J-B normality test, and the heteroskedasticity test with $p$ values of $0.2211,0.658535$, and 0.5349 , respectively. The normality test is also presented in Fig. 5.

\section{The structural stability test}

In the stability tests, a CUSUM and a CUSUM square point were introduced to increase the stability of the long-run and short-run parameters. The graphs of both the CUSUM test and CUSUM square test are mentioned in Figs. 6 and 7 which also specifies that all values lie within the critical boundaries at a significance level of $5 \%$. This allows us to confirm the long-run and short-run parameters' stability over the period of 1991-2014.

\section{Conclusions and policy implications}

Pakistan's electricity sector continues to face challenges in addition to its current energy crisis due to inconsistent energy production. This study investigated the access of both rural and urban populations to electricity as well as the impact of this access on Pakistan's economic growth. The ARDL bounds testing approach and a co-integration test were used to examine the dynamic causality relationship between the dependent and independent variables. The long-run relationship between the variables revealed that the access of rural and urban populations to electricity had a positive relationship with economic growth. Our study results suggest that the

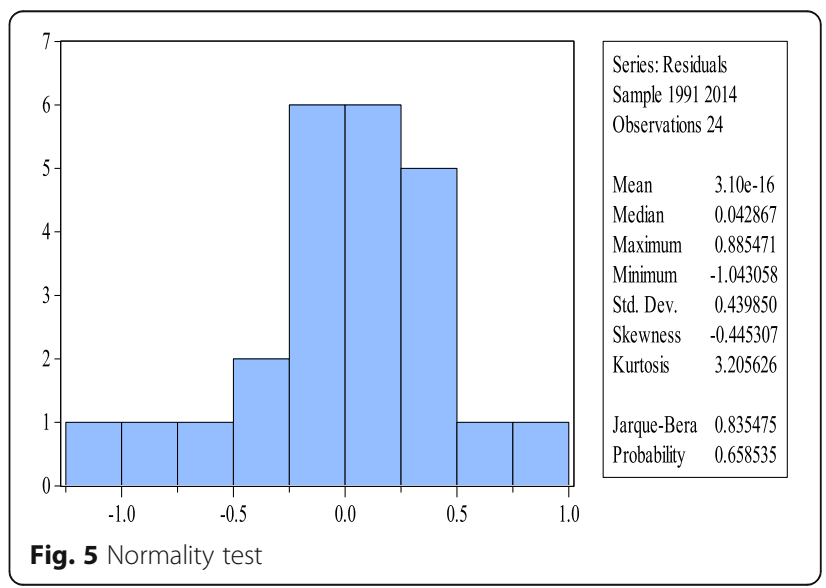




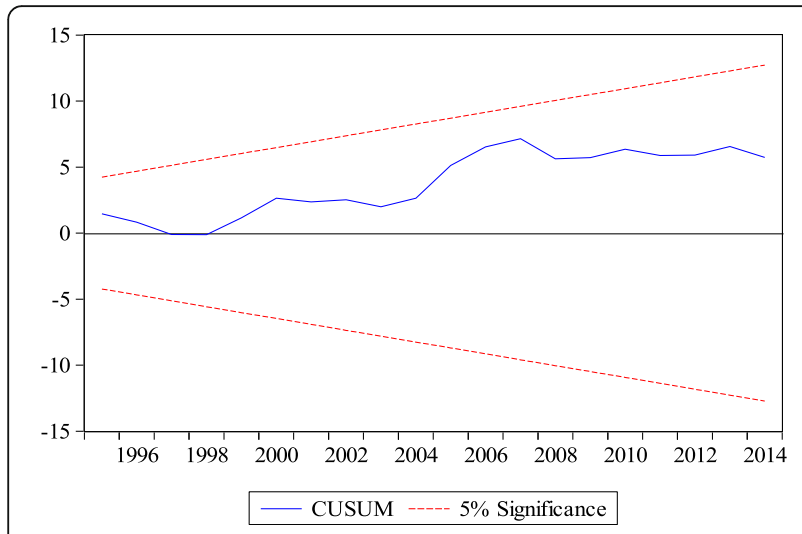

Fig. 6 CUSUM test

government of Pakistan has enhanced policies regarding electricity production from different sources including production from natural gas, the solar system, hydroelectric sources, nuclear sources, and wind power generators to fulfill the national demand. Pakistan can produce cheap electricity from natural gas which is one of the most dominant sources of energy, as is oil. To meet the increasing electricity demand of both rural and urban populations, the government should enhance their energy policies and increase financial support to boost electricity production. Pakistan has rich natural gas production and should explore this advantage. Natural gas is a viable and low-cost alternative for producing electricity. Recently, Pakistan is facing a water crisis, so that electricity production from hydropower cannot fulfill the demands. Likewise, the government should implement short-term and long-term energy policies to face Pakistan's energy crisis. The government needs to concentrate on a better utilization of resources and pay attention to the discourse regarding debt circulation and issuance immediately, in order to restructure the revenue

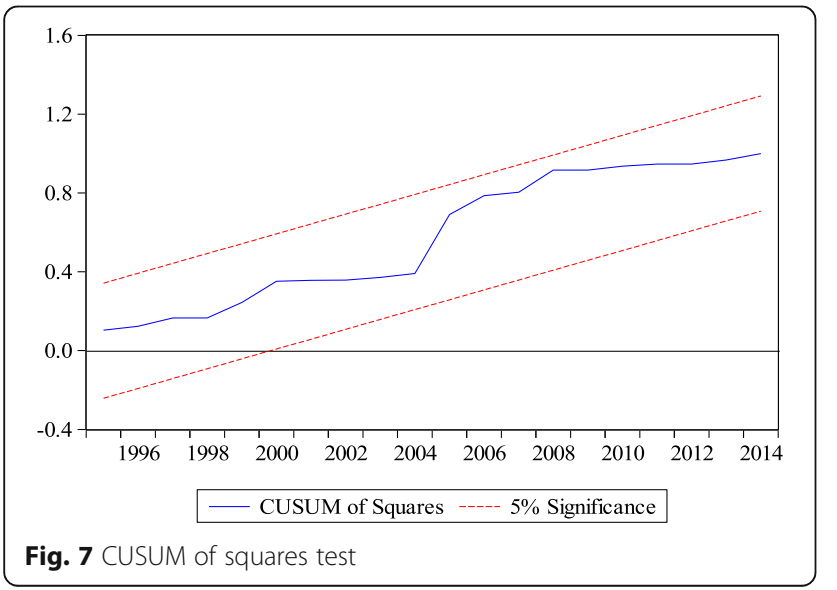

collection system and enhance rational energy production payments to the companies. This would create an easy way for power generation companies to attain funds and produce cheap electricity. The government should also build new dams and transfer thermal energy sources to other reliable sources with the aim to produce more electricity. As for a long-term energy production policy, the government should invest in alternative energy sources such as wind-powered generation. This will improve the country's electricity situation and enable the production of cheap electricity. Moreover, the authors recommend that the production of electricity from cheap and alternative sources receive more attention to improve the infrastructure, economic growth, and sustainable development of Pakistan.

\section{Acknowledgements}

The authors are grateful to the Research Centre of Agricultural-RuralPeasants, Anhui University Hefei, China for its financial and moral support. Moreover, the authors are also indebted to the reviewers for their positive suggestions that helped to improve the content of this study.

\section{Funding}

The paper was supported by the Research Centre of Agricultural-RuralPeasants, Anhui University Hefei, China.

\section{Availability of data and materials}

All data and material is available in this paper, so there is no other data to present.

\section{Authors' contributions}

AR conceived the study, collected the data, and estimated the econometric model. $Z D$ and AAC drafted the manuscript. $I H$ read and made suggestions to the manuscript. All authors read and approved the final manuscript.

\section{Ethics approval and consent to participate}

It is declared that this paper does not involve any human participants, human data or human tissue.

\section{Consent for publication}

This paper does not include any individual person's data in any form (including any individual details, images or videos).

Competing interests

The authors declare that there is no competing interest.

\section{Publisher's Note}

Springer Nature remains neutral with regard to jurisdictional claims in published maps and institutional affiliations.

\section{Author details}

${ }^{1}$ Research Center of Agricultural-Rural-Peasants, Anhui University, Hefei, China. ${ }^{2}$ College of Economics, Sichuan Agricultural University, Chengdu, China. ${ }^{3}$ Allama lqbal Open University, Islamabad, Pakistan.

Received: 21 May 2018 Accepted: 29 November 2018

Published online: 19 December 2018

\section{References}

1. Alter N, Syed SH (2011) An empirical analysis of electricity demand in Pakistan. Int J Energy Econ Policy 1(4):116

2. ET (2008). Energy tribune. Pakistan's ongoing electricity shortage (Accessed 18 Nov 2011 from /http://www.energytribune.com/articles.cfm?aid=864S)

3. Government of Pakistan, (2013). National Power Policy Pakistan 
4. OSEC (2010). Pakistan Power Sector (Accessed 18 Dec 2017 from/http:// www.osec.ch/sites/default/files/Pakistan-Power\%20sectorS.pdf)

5. ECSSR. (2004). Emirates center for strategic studies and research, Asian energy markets: dynamics and trend. Emirates center for strategic studies and research

6. Kessides IN (2013) Chaos in power: Pakistan's electricity crisis. Energy Policy 55:271-285. https://doi.org/10.1016/j.enpol.2012.12.005

7. Ponzo R, Dyner I, Arango S, Larsen ER (2011) Regulation and development of the Argentinean gas market. Energy Policy 39(3):1070-1079. https://doi. org/10.1016/j.enpol.2010.11.009

8. Naqvi M, Yan J, Dahlquist E, Naqvi SR (2016) Waste biomass gasification based off-grid electricity generation: a case study in Pakistan. Energy Procedia 103:406-412. https://doi.org/10.1016/j.egypro.2016.11.307

9. SESRIC, (2014). The statistical, economic and social research and training centre for Islamic countries. http://www.sesric.org

10. World Bank Data Pakistan (2014). [Accessed 30 Jan 2018], http://data. worldbank.org/country/pakistan.

11. Government of Pakistan, (2014). National power policy Pakistan

12. Alauddin M, Quiggin J (2008) Agricultural intensification, irrigation and the environment in South Asia: issues and policy options. Ecol Econ 65(1):111124. https://doi.org/10.1016/j.ecolecon.2007.06.004

13. Nawaz W, Arif M, Masood B (2014) Energy crises mitigation through available energy potential in Pakistan. Superior University, pp 1-10

14. Demirbaş A (2001) Biomass resource facilities and biomass conversion processing for fuels and chemicals. Energy Convers Manag 42(11):13571378. https://doi.org/10.1016/S0196-8904(00)00137-0

15. Purohit P, Tripathi AK, Kandpal TC (2006) Energetics of coal substitution by briquettes of agricultural residues. Energy 31(8):1321-1331. https://doi.org/ 10.1016/j.energy.2005.06.004

16. Demirbas A (2005) Potential applications of renewable energy sources, biomass combustion problems in boiler power systems and combustion related environmental issues. Prog Energy Combust Sci 31(2):171-192. https://doi.org/10.1016/j.pecs.2005.02.002

17. Leiby, R. (2012). Pakistan's power crisis may eclipse terrorist threat. The Washington Post./http://www.aboardthedemocracytrain.com/pakistanspower-crisismay-eclipse-terrorist-threats

18. Siddiqui R, Jalil HH, Nasir M, Malik WS, Khalid M (2008) The cost of unserved energy: evidence from selected industrial cities of Pakistan. Pak Dev Rev: 227-246 http://www.jstor.org/stable/23234709

19. Maxim A (2014) Sustainability assessment of electricity generation technologies using weighted multi-criteria decision analysis. Energy Policy 65:284-297. https://doi.org/10.1016/j.enpol.2013.09.059

20. Štreimikienè D, Šliogerienè J, Turskis Z (2016) Multi-criteria analysis of electricity generation technologies in Lithuania. Renew Energy 85:148-156. https://doi.org/10.1016/j.renene.2015.06.032

21. Valasai GD, Uqaili MA, Memon HR, Samoo SR, Mirjat NH, Harijan K (2017) Overcoming electricity crisis in Pakistan: a review of sustainable electricity options. Renew Sust Energ Rev 72:734-745. https://doi.org/10. 1016/j.rser.2017.01.097

22. Atems B, Hotaling C (2018) The effect of renewable and nonrenewable electricity generation on economic growth. Energy Policy 112:111-118. https://doi.org/10.1016/j.enpol.2017.10.015

23. Rehman A, Deyuan Z (2018) Pakistan's energy scenario: a forecast of commercial energy consumption and supply from different sources through 2030. Energy, Sustainability and Society 8(1):26. https://doi.org/10. 1186/s13705-018-0167-y

24. Sultan, M., Wu, J., e Aleem, F., \& Imran, M. (2018). Cost and energy analysis of a grid-tie solar system synchronized with utility and fossil fuel generation with major issues for the attenuation of solar power in Pakistan. Sol Energy, 174, 967-975. https://doi.org/10.1016/j.solener.2018. 09.052

25. Ashfaq A, lanakiev A (2018) Features of fully integrated renewable energy atlas for Pakistan; wind, solar and cooling. Renew Sust Energ Rev 97:14-27. https://doi.org/10.1016/j.rser.2018.08.011

26. Tahir ZR, Asim M (2017) Surface measured solar radiation data and solar energy resource assessment of Pakistan: a review. Renew Sust Energ Rev. https://doi.org/10.1016/j.rser.2017.06.090

27. Ebrahim Z (2012) Pakistan energy shortfall fuels row over coal power plants. The Guardian

28. NEPRA (National Electric Power Regulatory Authority) (2011). State of industry report 2011. /http://nepra.org.pk/industryreports.htm
29. Shahbaz M (2011) Electricity consumption. In: Financial development and economic growth nexus: a revisit study of their causality in Pakistan. University Library of Munich

30. Government of Pakistan, (2015). National power policy Pakistan

31. Nawaz S, lqbal N, Anwar S (2013) Electricity demand in Pakistan: a nonlinear estimation. Pak Dev Rev:479-491

32. Nasir M, Tariq MS, Arif A (2008) Residential demand for electricity in Pakistan. Pak Dev Rev:457 467 http://www.jstor.org/stable/41261234

33. HAWA, (2014). Hawa Power Project

34. Malik A (2012) Power crisis in Pakistan: a crisis in governance? (No. 2012: 4). Pakistan Institute of Development Economics

35. Jamil F, Ahmad E (2010) The relationship between electricity consumption, electricity prices and GDP in Pakistan. Energy Policy 38(10):6016-6025. https://doi.org/10.1016/j.enpol.2010.05.057

36. Institute of Public Policy (IPP) (2010) State of the economy: pulling back from the Abyss. Third Annual Report. Beaconhouse National University, Lahore

37. National Transmission and Despatch Company of Pakistan (NTDC) (2011). Electricity demand forecast based on regression analysis

38. Government of Pakistan (2017) Economic survey of Pakistan 2016-17. Ministry of Petroleum \& Natural Resources, Hydrocarbon Development Institute of Pakistan (HDIP)

39. Javadi FS, Rismanchi B, Sarraf M, Afshar O, Saidur R, Ping HW, Rahim NA (2013) Global policy of rural electrification. Renew Sust Energ Rev 19:402416. https://doi.org/10.1016/j.rser.2012.11.053

40. Agbemabiese L, Nkomo J, Sokona Y (2012) Enabling innovations in energy access: an African perspective. Energy Policy 47:38-47. https://doi.org/10. 1016/j.enpol.2012.03.051

41. Chaurey A, Krithika PR, Palit D, Rakesh S, Sovacool BK (2012) New partnerships and business models for facilitating energy access. Energy Policy 47:48-55. https://doi.org/10.1016/j.enpol.2012.03.031

42. Bhattacharyya SC, Ohiare S (2012) The Chinese electricity access model for rural electrification: approach, experience and lessons for others. Energy Policy 49:676-687. https://doi.org/10.1016/j.enpol.2012.07.003

43. Davidson O, Mwakasonda SA (2004) Electricity access for the poor: a study of South Africa and Zimbabwe. Energy for Sustainable Development 8(4): 26-40. https://doi.org/10.1016/S0973-0826(08)60511-6

44. Gómez MF, Silveira S (2010) Rural electrification of the Brazilian AmazonAchievements and lessons. Energy Policy 38(10):6251-6260. https://doi.org/ 10.1016/j.enpol.2010.06.013

45. Rehman IH, Kar A, Banerjee M, Kumar P, Shardul M, Mohanty J, Hossain I (2012) Understanding the political economy and key drivers of energy access in addressing national energy access priorities and policies. Energy Policy 47:27-37. https://doi.org/10.1016/j.enpol.2012.03.043

46. Mahmood A, Javaid N, Zafar A, Riaz RA, Ahmed S, Razzaq S (2014) Pakistan's overall energy potential assessment, comparison of LNG, TAPI and IPI gas projects. Renew Sust Energ Rev 31:182-193. https://doi.org/ 10.1016/j.rser.2013.11.047

47. Chaudhry S (2011) Circular debt in power sector reaches Rs 664.52 billion. Daily Times. November, p 18

48. Government of Pakistan (2016) Economic survey of Pakistan 2015-16. Ministry of Petroleum \& Natural Resources, Hydrocarbon Development Institute of Pakistan (HDIP)

49. Wakeel M, Chen B, Jahangir S (2016) Overview of energy portfolio in Pakistan Energy Procedia 88:71-75. https://doi.org/10.1016/j.egypro.2016.06.024

50. Rafique MM, Rehman S (2017) National energy scenario of PakistanCurrent status, future alternatives, and institutional infrastructure: an overview. Renew Sust Energ Rev 69:156-167. https://doi.org/10.1016/j. rser.2016.11.057

51. Dickey DA, Fuller WA (1979) Distribution of the estimators for autoregressive time series with a unit root. J Am Stat Assoc 74(366a):427-431

52. Pesaran $M H$, Shin $Y$ (1998) An autoregressive distributed-lag modelling approach to cointegration analysis. Econ Soc Monographs 31:371-413

53. Pesaran MH, Shin Y, Smith RJ (2001) Bounds testing approaches to the analysis of level relationships. J Appl Econ 16(3):289-326. https://doi. org/10.1002/jae.616

54. Narayan PK (2004) Reformulating critical values for the bounds Fstatistics approach to cointegration: an application to the tourism demand model for Fiji, Dissertation. Monash University

55. Arshad M, Bano I, Khan N, Shahzad MI, Younus M, Abbas M, labal M (2018) Electricity generation from biogas of poultry waste: an assessment of 
potential and feasibility in Pakistan. Renew Sust Energ Rev 81:1241-1246. https://doi.org/10.1016/..rser.2017.09.007

56. Akber MZ, Thaheem MJ, Arshad H (2017) Life cycle sustainability assessment of electricity generation in Pakistan: policy regime for a sustainable energy mix. Energy Policy 111:111-126. https://doi.org/10. 1016/j.enpol.2017.09.022

57. Kamran M (2018) Current status and future success of renewable energy in Pakistan. Renew Sust Energ Rev 82:609-617. https://doi.org/10.1016/j.rser. 2017.09.049

58. Irfan M, lqbal J, lqbal A, lqbal Z, Riaz RA, Mehmood A (2017) Opportunities and challenges in control of smart grids-Pakistani perspective. Renew Sust Energ Rev 71:652-674. https://doi.org/10.1016/j.rser.2016.12.095

Ready to submit your research? Choose BMC and benefit from:

- fast, convenient online submission

- thorough peer review by experienced researchers in your field

- rapid publication on acceptance

- support for research data, including large and complex data types

- gold Open Access which fosters wider collaboration and increased citations

- maximum visibility for your research: over $100 \mathrm{M}$ website views per year

At BMC, research is always in progress.

Learn more biomedcentral.com/submissions 